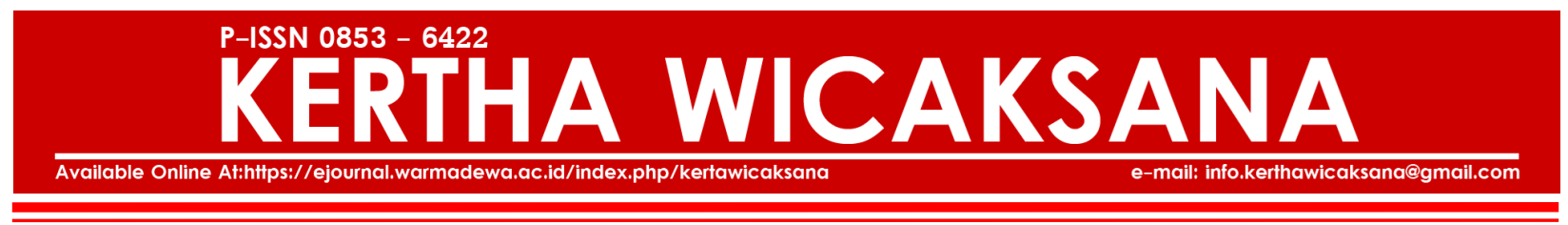

\title{
KARAKTERISTIK KEBIJAKAN PENDIDIKAN TINGGI HUKUM INDO- NESIA BERDASARKAN PANCASILA DAN UNDANG-UNDANG DASAR NEGARA REPUBLIK INDONESIA TAHUN 1945
}

\author{
Jawade Hafidz \\ Fakultas Hukum Universitas Islam Sultan Agung \\ E-mail: jawade.hafidz@yahoo.com \\ DOI: $10.22225 / \mathrm{kw} \cdot 12 \cdot 1.420 .22-37$ \\ Halaman: 22 - 37

\begin{abstract}
Abstrak
Pendidikan adalah hak setiap warga Negara sebagaimana diamanatkan dalam pasal 31 Undang-Undang Dasar Negara Republik Indonesia 1945. Pendidikan tinggi yang merupakan bagian dari sistem pendidikan nasional memiliki peran strategis dalam mencerdaskan kehidupan bangsa dan memajukan ilmu pengetahuan dan tekonologi. Lulusan pendidikan tinggi hukum diharuskan untuk dapat bersaing di dalam era globalisasi, tidak hanya dengan sesama lulusan sarjana hukum, akan tetapi juga dengan profesi lainnya. Lulusan pendidikan tinggi hukum harus mempunyai daya saing global dengan penguasaan bahasa asing yang mumpuni khususnya tentang ilmu hukum.
\end{abstract}

Kata kunci : Ilmu Pengetahuan, Pendidikan Tinggi, Ilmu Hukum

\begin{abstract}
Education is the right of every citizen as mandated in article 31 of the Constitution of the Republic of Indonesia 1945. High education which is part of the national education system has a strategic role in educating the nation's life and advancing science and technology. Graduates of higher education law are required to be able to compete in the era of globalization, not only with graduates of law graduates, but also with other professions. Higher education graduates of law must have global competitiveness with a mastery of a qualified foreign language, especially about the science of law.
\end{abstract}

Keywords: Science, Higher Education, Legal Studies

\section{PENDAhuluan}

Pendidikan adalah sebuah kata yang selama ini menjadi tolak ukur masyarakat untuk menyebut intelektualitas seseorang. Semakin tinggi tingkat pendidikan, akan semakin mudah untuk mendapatkan pekerjaan dan menuju kesuksesan. Ada benarnya demikian, akan tetapi kesuksesan seseorang juga dibarengi dengan skill dan kemauan atau tekad yang tinggi.

Mengutip kata-kata Presiden Soekarno bahwa : "Bangsa yang besar adalah bangsa yang mampu mewujudkan mimpi yang besar". Perwujudan itu memer-lukan sejumlah syarat. Salah satu jembatan yang perlu mendapat perhatian serius adalah pendidikan ${ }^{1}$.

Memperoleh pendidikan adalah hak setiap warga negara, dan ini termasuk ke dalam hak asasi manusia yang harus dijunjung tinggi. Di dalam Alinea Keempat Pembukaan Undang-Undang Dasar Negara Republik Indonesia Tahun 1945 disebutkan pula tujuan dari bangsa Indonesia, yakni :

Kemudian daripada itu untuk membentuk suatu Pemerintah Negara Indonesia yang melindungi segenap bangsa Indonesia dan seluruh tumpah darah Indonesia dan untuk memajukan kesejahteraan umum, mencerdaskan kehidupan bangsa dan ikut melaksanakan ketertiban dunia yang berdasarkan kemerdekaan, perdamaian abadi dan keadilan sosial, maka disusunlah kemerdekaan kebangsaan Indonesia itu dalam suatu Undang-Undang Dasar Negara Indonesia, yang terbentuk dalam suatu susunan Negara Re-

1. Forum Mangunwijaya, Kurikulum yang Mencerdaskan, Visi 2030 dan Pendidikan Alternatif, Cetakan Pertama, Kompas Media Nusantara, Jakarta, 2007, hlm. 97 dan 98. 
publik Indonesia, yang berkedaulatan rakyat dengan berdasar kepada : Ketuhanan Yang Maha Esa, Kemanusiaan yang Adil dan Beradab, Persatuan Indonesia dan Kerakyatan yang Dipimpin oleh Hikmat Kebijaksanaan Dalam Permusyawaratan/Perwakilan, serta dengan mewujudkan suatu Keadilan Sosial Bagi Seluruh Rakyat Indonesia.

Terkait dengan penyelenggaraan pendidikan oleh Negara Republik Indonesia, sebagaimana tujuan bangsa Indonesia untuk mencerdaskan kehidupan bangsa, maka dalam Pasal 31 Undang-Undang Dasar Negara Republik Indonesia Tahun 1945 mengamanatkan bahwa :

1) Setiap warga negara berhak mendapat pendidikan;

2) Setiap warga negara wajib mengikuti pendidikan dasar dan pemerintah wajib membiayainya;

3) Pemerintah mengusahakan dan menyelenggarakan satu sistem pendidikan nasional, yang meningkatkan keimanan dan ketakwaan serta akhlak mulia dalam rangka mencerdaskan kehidupan bangsa, yang diatur dengan undangundang;

4) Negara memprioritaskan anggaran pendidikan sekurang-kurangnya dua puluh persen dari anggaran pendapatan dan belanja negara serta dari anggaran pendapatan dan belanja daerah untuk memenuhi kebutuhan penyelenggaraan pendidikan nasional;

5) Pemerintah memajukan ilmu pengetahuan dan teknologi dengan menjunjung tinggi nilai-nilai agama dan persatuan bangsa untuk kemajuan peradaban serta kesejahteraan umat manusia.

Tujuan pendidikan adalah untuk mencerdaskan kehidupan bangsa. Seluruh rakyat Indonesia tanpa terkecuali. Pendidikan merupakan salah satu dalam upaya pembangunan bangsa, dalam hal ini adalah meningkatkan sumber daya manusia Indonesia yang berkualitas. Hal itu terus-menerus dilakukan sebagai tugas utama pemerintah Negara Kesatuan Republik Indonesia. Ukuran utama bagi keberhasilan pemerintahan Negara Indonesia sebagaimana digariskan oleh para pendiri Republik Indonesia seharus-nya adalah ${ }^{2}$ :

1) Terlindunginya segenap bangsa Indonesia dan tumpah darah Indonesia, di mana pun darah Indonesia tumpah termasuk darahnya para Tenaga Kerja Indonesia, harus terlindungi;

2) Majunya kesejahteraan umum dan kemakmuran rakyat;
3) Cerdasnya kehidupan bangsa; dan

4) Bermartabatnya kedudukan Indonesia dalam percaturan global baik po-litik, ekonomi, serta ilmu pengetahuan dan teknologi (iptek); dan

5) Bukan hanya terlaksana tidaknya demokrasi sebagai suatu sarana untuk mencapai tujuan.

Sumber daya manusia yang berkualitas akan membuat suatu bangsa menjadi disegani oleh bangsa lainnya, dan melalui pendidikanlah semua dapat diwujudkan. Dirumuskan secara singkat bersahaja, "pendidikan" bermakna bimbingan/ pimpinan dalam pertumbuhan perkembangan hidup manusia (opvoeding is leiding bij's mensen groei). Tujuan pendidikan adalah membentuk manusia merdeka lahir batin $^{3}$.

Jenjang yang harus ditempuh dari Taman KanakKanak, Sekolah Dasar, Sekolah Menengah Pertama, Sekolah Menengah Atas hingga Perguruan Tinggi yang dikenal sebagai pendidikan formal, merupakan suatu proses untuk mencetak generasi bangsa yang berkualitas, bermoral, dan berdedikasi tinggi.

Kenyataan yang diungkap mengandung makna bahwa pendidikan, termasuk dan terutama pendidikan tinggi merupakan faktor yang menentukan keberhasilan pem-bangunan suatu negara, terutama ekonomi ${ }^{4}$.

Kotler me-nyatakan bahwa: "The main institutional mechanism for building up human capital is the formal educational system". Selanjutnya tokoh lain, yaitu George Psakarapoulos dan Maureen Woodhall menyata-kan bahwa : "Formal education fulfils a basic human need for knowledge and provide a means of helping to meet other basic needs. Its contribution to social and economic activities are pervasive. Education facilitates the process of industri-alization by improving the quality of the labor force 5 ".

Terjemahan bebas penulis "The main institutional mechanism for building up human capital is the formal educational system" bahwa untuk membangun manusia yang baik dan berkualitas ditempuh melalui lembaga pendidikan formal. "Formal education fulfils a basic human need for knowledge and provide a means of helping to meet other basic needs. Its contribution to social and economic activities are pervasive. Education facilitates the process of industri-alization by improving the quality of the labor force" bahwa pendidikan formal memenuhi kebutuhan dasar manusia untuk pengetahuan dan menyediakan sarana untuk membantu memenuhi kebutuhan dasar lainnya. Kontribusinya terhadap kegiatan sosial dan ekonomi yang meluas. Pendidikan memfasilitasi proses industrialisasi dengan meningkatkan kualitas tenaga kerja.

2. Ibid., hlm. 4.

3. Abdul Ghofur Anshori dan Shobirin Malian (Ed.), Membangun Hukum Indonesia, Kumpulan Pidato Guru Besar Ilmu Hukum dan Filsafat, Cetakan Pertama, Kreasi Total Media, Yogyakarta, 2008, hlm. 59 dan 60.

4. Forum Mangunwijaya, op.cit., hlm. 7.

5. Ibid., hlm. 31 . 
Dari penelitian Kotler diperoleh kesimpulan bahwa penentu kualitas sumber daya manusia yang mendukung proses industrialisasi adalah pendidikan formal. Selan-jutnya, Bank Dunia juga menyimpulkan : "That lack of education is greater obstacle than lack of physical assets. In addition, education also act as a change agent in diseminating modern values and aspirations ${ }^{6,}$.

Terjemahan bebas penulis "That lack of education is greater obstacle than lack of physical assets. In addition, education also act as a change agent in diseminating modern values and aspirations" bahwa kurangnya pendidikan merupakan kendala besar dari kurangnya aset fisik. Selain itu, pendidikan juga bertindak sebagai agen perubahan dalam menyebarkan informasi nilai dan aspirasi yang modern.

Kesimpulan yang ditarik oleh Kotler tentang peranan strategis pendidikan formal dalam pembangunan ekonomi, bahwa tanpa pendidikan (lack of education) merupakan penghalang besar bagi pembangunan ekonomi dari aset lainnya, karena melalui manusia terdidik akan diseminasikan nilai-nilai yang relevan dengan pembangunan ekonomi ${ }^{7}$.

Secara umum, suatu perusahaan besar akan lebih mengutamakan tingkat pendidikan dalam mencari pegawai atau karyawan. Pendidikan tinggi dinilai lebih memiliki wawasan yang luas dan lebih terampil dibandingkan jenjang pendidikan di bawahnya.

Pendidikan tinggi, saat ini menjadi syarat dalam mencari sebuah pekerjaan atau menjalankan suatu profesi, sehingga banyak perguruan tinggi atau universitas menawarkan berbagai jurusan dan mencetak banyak sarjana, tentunya yang diharapkan adalah sarjana yang berkualitas.

Sebagai contoh adalah negara India, misalnya, yang pada tahun 2005 berada di luar 10 besar diramalkan pada 2040 masuk menjadi nomor tiga. India diramalkan menghasilkan hampir 700.000 sarjana Ilmu Pengetahuan Alam (IPA) dan teknik yang pada tahun 1990-1991 baru lebih kurang 200.000 sarjana. China yang pada 1990-1991 menghasilkan 200.000 sarjana Ilmu Pengetahuan Alam dan teknik, tahun 2004 menghasilkan lebih dari 500.000 sarjana. Amerika Serikat yang pada 1990-1991 menghasilkan lebih dari 300.000 sarjana Ilmu Pengetahuan Alam dan teknik, tahun 2004 telah menghasilkan 400.000 sarjana. Cerita sukses mereka menunjukkan bahwa pendidikan, utamanya pendidikan tinggi, merupakan faktor yang menentukan keberhasilan pembangunan negara, terutama ekonomi ${ }^{8}$.

Salah satu dari jenis pendidikan tinggi yang dita- warkan oleh sebuah universitas adalah jurusan ilmu hukum atau pendidikan tinggi hukum. Pendidikan tinggi hukum selama ini telah mencetak para sarjana hukum yang kemudian mengisi jabatan di pemerintahan, penegak hukum, maupun profesi (seperti pengacara dan notaris). Para sarjana hukum yang handal adalah lulusan yang ingin dicetak di setiap perguruan tinggi hukum. Tidak hanya handal tetapi juga mempunyai integritas tinggi, mempunyai rasa kemanusiaan, memiliki kejujuran, dapat bersikap adil, dan mempunyai ketaqwaan terhadap Tuhan Yang Maha Esa.

Sejak pendidikan hukum pertama kali diperkenalkan di Indonesia oleh pemerintah kolonial Belanda, maka pendidikan hukum mengalami pergulatan hebat sepanjang sejarah perkembangannya. Seperti diketahui, masyarakat Indonesia sebelum datangnya penjajah tidak mengenal pendidikan hukum dalam sebuah institusi yang sifatnya formal. Orde hukum yang dijalankannya merupakan orde hukum adat yang didasari oleh nilai-nilai keadilan. Ahli-ahli hukum yang melaksanakannya bukanlah merupakan alumni dari institusi pendidikan hukum resmi melainkan lahir dari pengakuan masyarakat akan keunggulan dan kelebihannya secara kultural ${ }^{9}$.

Institusi pendidikan hukum yang pertama kali diperkenalkan kepada masyarakat pribumi pada masa itu adalah rechtshogeschool yang setara dengan sekolah pendidikan tinggi hukum. Institusi pendidikan hukum tersebut diharapkan mampu menghasilkan lulusan yang mempunyai keahlian mengoperasikan orde hukum karena undang-undang merupakan satu-satunya hukum. Senada dengan hal tersebut, Soetandyo Wignyosoebroto menyatakan bahwa di sekolah-sekolah tinggi hukum tersebut, materi kuliah diberikan dengan tujuan utama agar para mahasiswa menguasai sejumlah kaidah hukum yang tertuang dalam peraturan perundang-undangan yang harus dipahami menurut tradisi reine rechtslehre kelsenian, yang memodelkan hukum sebagai suatu sistem normatif yang tertutup dalam pengguna-annya harus dipandang tak ada hubungan logis dengan kenyataan empiris yang dialami orang di lapangan ${ }^{10}$.

Hukum yang semula menjadi milik masyarakat dan tempat untuk mengetuk keadilan harus teralienasi dan berjarak dengan masyarakatnya, karena yang berhak menjalankannnya hanya ahli hukum lulusan sekolah formal, yaitu sekolah tinggi hukum bentukan pemerintahan jajahan. Masyarakat yang ingin berurusan dengan hukum dan keadilan harus meminta izin dan melewati berbagai tahap prosedur biro-kratis. Tidak sembarang orang yang kemudian bebas untuk

6. Ibid.

7. Ibid., hlm 32 .

8. Ibid., hlm. 98 dan 99.

9. Satjipto Rahardjo, Pendidikan Hukum Sebagai Pendidikan Manusia, Kaitannya Dengan Profesi Hukum dan Pembangunan Hukum Nasional, Cetakan Kesatu, Genta Publishing, Yogyakarta, 2009, hlm. vii.

10. Ibid., hlm. vii dan viii. 
berurusan dengan hu-kum, melainkan hanyalah orang yang berpunya (the haves) yang berhak untuk itu ${ }^{11}$.

Keadilan pada saat itu memang tidak didapatkan oleh masyarakat jajahan, karena adanya perbedaan golongan yang diterapkan oleh pemerintah penjajah. Keadilan pada zaman itu menjadi barang yang sangat mahal bagi pencari keadilan, yakni masyarakat pribumi yang mayoritas tidak mengenal hukum.

Pendidikan tinggi hukum di Indonesia berubah dan berkembang dari waktu ke waktu. Pendidikan berubah dan berkembang terus mengikuti perkembangan masyarakatnya. Setiap kali dalam kurun waktu tertentu dalam sejarah muncul "new directions inlegal education”, bahkan untuk negara yang sangat maju, seperti Amerika Serikat sekalipun ${ }^{12}$.

Untuk negara Indonesia sendiri, mempunyai ciri khusus dalam penyelenggaraan pendidikan tinggi hukum, yakni dengan bersumber pada ajaran agama sebagai basis filosofisnya, sebagaimana yang terdapat di dalam sila Pancasila terutama Sila Ketuhanan Yang Maha Esa dan Kemanusiaan Yang Adil dan Beradab. Sebagai landasan yuridisnya, sebagaimana disebutkan di atas adalah Pasal 31 Undang-Undang Dasar Negara Republik Indonesia Tahun 1945.

Dari segi sosiologis, masyarakat sangat membutuhkan pendidikan. Tidak hanya untuk status sosial, tetapi juga dalam mencari pekerjaan. Dalam dunia pendidikan, terjadi interaksi sosial. Satu dan yang lainnya akan saling bertukar pikiran. Selain itu, apa yang diajarkan oleh pendidik akan membawa pengaruh bagi anak didiknya, terutama dalam pembangunan kualitas sumber daya manusia dan karakter anak didik yang dihasilkan.

Untuk pendidikan tinggi diatur di dalam UndangUndang Nomor 12 Tahun 2012 tentang Pendidikan Tinggi; Peraturan Menteri Pendidikan dan Kebudayaan Republik Indonesia Nomor 49 Tahun 2014 tentang Standar Nasional Pendidikan Tinggi, Peraturan Menteri Riset, Teknologi, dan Pendidikan Tinggi Republik Indonesia Nomor 44 Tahun 2015 tentang Standar Nasional Pendidikan Tinggi; Peraturan Pemerintah Nomor 66 Tahun 2010 tentang Perubahan Atas Peraturan Pemerintah Nomor 17 Tahun 2010 tentang Pengelolaan dan Penyelenggaraan Pendidikan, dan Peraturan Pemerintah Nomor 4 Tahun 2014 tentang Penyelengga -raan Pendidikan Tinggi dan Pengelolaan Perguruan Tinggi.

Barangkali tidak ada di antara sekian banyak fakultas dalam lingkungan universitas yang menawarkan pendidikan yang begitu komplit seperti fakultas hukum. Dikatakan lengkap, karena selain memberikan ketrampilan teknologis, Fakultas Hukum juga membentuk mahasiswa menjadi manusia budaya. Dengan demikian, sarjana hukum selain teknokrat juga budayawan. Fakultas Hukum membekali alumninya dengan suatu sikap dan pengetahuan dasar untuk nantinya dapat mengembangkan dirinya sebagai seorang intelektual. Jadi pendidikan hukum juga berciri pendidikan suatu kualitas manusia dan intelektual berkemampuan umum yang luas ${ }^{13}$.

Maraknya kasus hukum yang terjadi di Indonesia, mengindikasikan bahwa saat ini Negara Republik Indonesia sangat membutuhkan lulusan para sarjana hukum yang handal dan profesional dalam menangani kasus bersangkutan. Tidak hanya handal dan profesional, akan tetapi juga para sarjana hukum yang mempunyai ketaqwaan tinggi kepada Tuhan Yang Maha Esa dan berperikemanusiaan, sebagaimana tertuang dalam Sila Pertama dan Kedua Pancasila. Segala cita-cita gagasan-gagasan, maupun ide-ide bangsa Indonesia tertuang dalam Pancasila.

Pendidikan hukum juga menduduki posisi penting dalam pengembanan hukum. Pendidikan hukum tidak hanya harus peka terhadap kondisi dan realitas masyarakatnya, melainkan pendidikan hukum harus menempatkan dirinya sebagai arsenal pembangunan hukum yang beridentitas Indonesia. Pendidikan hukum merupakan rahim untuk melahirkan lulusan yang akan mengoperasikan dan menjalankan sistem hukum (legal order) dalam jagat ketertiban ${ }^{14}$.

Sarjana hukum yang baik, harus mengikuti koridor hukum. Tidak boleh melakukan penyimpangan dan mencari celah dalam peraturan perundang-undangan untuk kepentingan pribadinya. Mereka tahu, mana yang baik dan tidak, mana yang benar dan yang salah.

Pendidikan hukum harus mengintrodusir cara pandang baru yang mengutuhkan (holisitik), sehingga pendidikan hukum bukan untuk melahirkan manusia yang kompetitif dan mampu bersaing melainkan lulusan yang mampu mendistribusikan nilai-nilai ilahiah seperti keadilan, kebenaran, dan kejujuran sebagai dasar eksistensi hukum untuk menjadi alat perekat sosial (social unity). Ilmu pada dasarnya harus mampu memberi pencerahan pada komunitas yang dilayani ${ }^{15}$.

Nilai-nilai tersebut, nantinya akan diterapkan dalam pekerjaan hukum yang digelutinya. Pendidikan tinggi hukum di Indonesia harus mempunyai karakteristik yang berbeda, dengan Pancasila sebagai dasar filosofisnya dan Undang-Undang Dasar Negara Republik Indonesia Tahun 1945 sebagai dasar yuridisnya.

Salah satu profesi atau pekerjaan hukum yang mulia adalah lawyer. Profesi ini yang paling banyak mendominasi saat ini. Hanya saja di Indonesia, para lawyer ini masih kalah bersaing dengan lawyer dari

\footnotetext{
11. Ibid.

12. Ibid., hlm. 18.

13. Ibid., hlm. 45 dan 46.

14. Ibid., hlm. xi dan xii.

15. Ibid., hlm. xiv.
} 
luar negeri, karena adanya hambatan yang salah satunya dari segi bahasa.

Lahan bagi beroperasinya pekerjaan hukum sekarang sudah mendunia. Batas-batas negara tidak lagi menjadi penghalang bagi para lawyering untuk melakukan pekerjaannya. Fenomena mega lawyering yang dimulai dari Amerika Serikat, sekarang tampaknya sudah boleh mengklaim sebagai global-lawyering. Mega-lawyering juga tidak lain merupakan bagian dari masuknya kapitalisme ke dalam praktek lawyering. Praktek hukum tidak dapat lagi membatasi pekerjaannya sebagai murni pekerjaan hukum, melainkan semakin didesak untuk membuka pintu bagi masuknya pelayanan terhadap ekonomi kapitalis. Dengan demikian, hukum dan bisnis sudah bercampur menjadi satu model lawyering yang baru ${ }^{16}$.

Mega-lawyering merupakan praktek yang dicirikan oleh sejumlah karakteristik tertentu yang memberi warna kepada praktek hukum Amerika modern, yaitu yang bersifat korporatif atau memiliki segmen organisasi kuat. Karakteristik tersebut dengan singkat dapat disebut "praktek dalam unit $\square$ unit yang lebih besar" ${ }^{17 \text { " }}$

Meskipun demikian, tetap perlu diperhatikan bahwa bangsa Indonesia mempunyai dasar falsafah Pancasila yang didapatkan melalui proses yang panjang. Hal inilah yang membedakan dengan sistem ekonomi Amerika Serikat yang kapitalis, yang mana pekerjaan hukum bukanlah hanya untuk bisnis semata, tetapi juga membutuhkan hati nurani.

Dengan berguru pada rakyat, para pemimpin kita di masa lalu berhasil menggali ratna mutu manikan nilai dan ajaran hidup dari khazanah kepribadian bangsa, yang dirangkum menjadi kesatuan raras serasi, dan diberi nama Pancasila. Dengan belajar kepada rakyat pula, para pemimpin kita sekarang pun mampu menjabarkan Pandangan Hidup Bangsa dan Falsafah Negara itu ke dalam butir-butir ajaran hidup yang tiada ternilai harganya $^{18}$.

Oleh karena itu, pendidikan tinggi hukum harus dapat mencetak lulusan para sarjana hukum yang selalu siap mengamalkan nilai-nilai Pancasila dan UndangUndang Dasar Negara Republik Indonesia Tahun 1945 secara konsisten dan konsekuen, hal ini menjadi tantangan bagi setiap perguruan tinggi hukum di Indonesia.

Berdasarkan pada pendahuluan yang telah dikemukakan di atas, penulis merumuskan permasalahan berikut : Bagaimanakah karakteristik kebijakan pendidikan tinggi hukum Indonesia berdasarkan Pancasila dan Undang-Undang Dasar Negara Republik Indonesia Tahun 1945 ?

\section{PEMBAHASAN}

Pasal 1 angka 1 Undang-Undang Nomor 12 Tahun 2012 menyebutkan bahwa :

Pendidikan adalah usaha sadar dan terencana untuk mewujudkan suasana belajar dan proses pembelajaran agar peserta didik secara aktif mengembangkan potensi dirinya untuk memiliki kekuatan spiritual keagamaan, pengendalian diri, kepribadian, kecerdasan, akhlak mulia, serta ketrampilan yang diperlukan dirinya, masyarakat, bangsa, dan negara.

Pendidikan menjadi sangat penting keberadaannya, terkait peningkatan kemampuan dan cara pandang maupun cara berpikir seseorang. Pendidikan yang secara umum oleh masyarakat bertujuan untuk mencari ilmu pengetahuan dan pada hasil akhirnya sebagai sarana untuk mencari pekerjaan yang sesuai dengan tingkat pendidikan maupun yang sesuai dengan jurusannya.

Sejarah peradaban dunia menunjukkan peranan sistem persekolahan, terutama sejak era industrialisasi, dalam proses peradaban dunia menjadi modern, dan lebih dari itu, keberhasilan gerakan negara kebangsaan baik Jerman, Amerika Serikat, maupun negara kebangsaan lainnya juga berkat sistem pendidikan (persekolahan) nasional masing-masing negara tersebut $^{19}$.

Pendidikan sekarang ini tidak dapat dikesampingkan. Oleh karena dengan pendidikan akan dapat membawa pada perubahan suatu bangsa yang lebih beradab dan humanis.

Plato, empat abad Sebelum Masehi, sudah menempatkan pendidikan sebagai landasan dan pengawal tegaknya suatu masyarakat. Pendiri Republik menempatkan hak warga negara untuk memperoleh pendidikan, dan kewajiban pemerin-tah untuk mengusahakan dan menyelenggarakan satu sistem pengajaran nasional (persekolahan) dalam Undang-Undang Dasar Negara Republik Indonesia Tahun 1945, yaitu dalam Pasal $31^{20}$.

Bangsa Indonesia terus-menerus melakukan perbaikan dalam peningkatan kualitas pendidikannya. Tidak hanya berkutat pada teori-teori, akan tetapi juga bagaimana mengaplikasikannya ke dalam kehidupan sehari-hari. Oleh karena, ilmu yang diperoleh akan dipraktikkan.

Bangsa Indonesia patut bangga karena Indonesia adalah satu dari tidak banyak negara yang memasukkan ketentuan tentang pendidikan dalam UndangUndang Dasar. Hal ini dilaku-kan karena para pendiri Republik yakin bahwa misi membangun negara bangsa Indonesia yang cerdas kehi-dupannya, yaitu yang mod-

\footnotetext{
16. Ibid., hlm. 104.

17. Ibid.

18. Abdul Ghofur Anshori dan Shobirin Malian (Ed.), op.cit., hlm. 62.

19. Forum Mangunwijaya, op.cit., hlm. 9.

20. Ibid., hlm. 10 dan 11.
} 
ern, maju, dan demokratis hanya dapat dilakukan melalui pendidikan ${ }^{21}$.

Pendidikan tinggi yang merupakan bagian dari sistem pendidikan nasional memiliki peran strategis dalam mencerdaskan kehidupan bangsa dan memajukan ilmu pengetahuan dan teknologi. Pendidikan tinggi diharapkan dapat menjadi pen-cetak sumber daya manusia yang profesional, berdaya guna, dan bersaing, termasuk di sini adalah pendidikan tinggi hukum.

Pengertian pendidikan tinggi menurut Pasal 1 angka 2 Undang-Undang Nomor 12 Tahun 2012 adalah : "Jenjang pendidikan setelah pendidikan menengah yang mencakup program diploma, program sarjana, program magister, program doktor, dan program profesi, serta program spesialis, yang diselenggarakan oleh perguruan tinggi berdasarkan kebudayaan bangsa Indonesia".

Pada Pasal 2 Undang-Undang Nomor 12 Tahun 2012 disebutkan bahwa . Pendidikan tinggi berdasarkan Pancasila, Undang-Undang Dasar Negara Republik Indonesia Tahun 1945, Negara Kesatuan Republik Indonesia, dan Bhinneka Tunggal Ika.

Demikian pula pada pendidikan tinggi hukum di Indonesia penyelenggaraannya didasarkan pada nilainilai luhur Pancasila dan Undang-Undang Dasar Negara Republik Indonesia Tahun 1945. Keberadaan pendidikan tinggi hukum di Indonesia tidak terlepas dari sejarah sekolah hukum di Eropa.

Dalam sejarahnya, sekolah hukum pertama lahirnya di Eropa, yakni di kota Bologna, dan sekolah teologi yang di dalamnya ada jurusan hukum di Paris. Pada masa abad pertengahan, hukum mulai dikaitkan dengan sistem hukum tertentu. Pemikiran hukum sudah mulai dipandang sebagai hal yang konkret (tidak semata-mata bersifat abstrak lagi). Adanya sekolah hukum tersebut, mulai menandai pandangan tentang hukum sebagai ajaran, karena hukum di sini mulai dipelajari secara sistematis dan konkret. Perubahan ini mendorong lahirnya cabang-cabang baru yang memusatkan perhatiannya pada hukum (disiplin hukum ${ }^{22}$ ).

Di Indonesia, pendidikan tinggi hukum telah ada dihitung sejak didirikan Rechtshogeschool di Jakarta pada tahun 1924, memang usia pendidikan tinggi hukum di Indonesia adalah delapan puluh tahun. Tetapi sebelumnya sudah ada sekolah hukum yang didirikan pada tahun 1909, yang bernama Rechtsschool dengan lama pendidikan enam tahun di atas sekolah dasar. Tiga tahun pertama, sekolah tersebut berupa pendidikan lanjutan di atas sekolah dasar yang disebut MULO (Meer Uitgebreid Lager Ondervijs). Pada wak- tu itu, pendidikan hukum tingkat universitas belum dapat dibuka, karena sekolah lanjutan atas baru dibuka pada tahun 1919 yang disebut AMS (Algemeene Middelbare School). Banyak lulusan Rechts-school yang kemudian melanjutkan pendidikan ke tingkat universitas di negeri Belanda ${ }^{23}$.

Pemerintah kolonial Belanda membuka sekolahsekolah dan pendidikan tinggi tersebut sebagai balas jasa terhadap Indonesia yang telah dikeduk kekayaannya selama ratusan tahun. Indonesia pada waktu itu bernama Nederlands-Indie benar-benar menjadi pilar negeri Belanda. Hal tersebut dapat disimak dari kalimat "Indie verloren ruinpspoed geboren", artinya kehilangan Indonesia berarti mala-petaka) dan "Indie is de kurk waarop Nederland drijft" (Indonesia adalah gabus tempat negeri Belanda mengapung). Sistem tanam paksa yang disebut sebagai Cultuurstelsel juga merupakan bukti betapa Belanda secara sistematis mengeruk hasil-hasil pertanian Indonesia untuk menopang negerinya supaya bisa tetap survive. Sebab pada waktu itu, negeri Belanda benar-benar dalam keadaan hampir ambruk karena berbagai kemelut dan peperangan di dalam negerinya ${ }^{24}$.

Baru menjelang akhir masa penjajahan Belanda atas Indonesia, timbul kesadaran untuk memberi balas budi. Perubahan politik ini disebut sebagai ethische koers, yaitu perubahan ke arah pemerintahan yang lebih etis, karena tindakan-tindakan sebelumnya dengan mengeruk habis-habisan kekayaan Indonesia, dipandang sebagai suatu politik yang tidak etis ${ }^{25}$.

Pada awal pembukaan pendidikan tinggi hukum di Indonesia, pendidikan dirancang untuk menyiapkan tenaga terampil dalam menggunakan hukum positif. Lulusannya bergelar "meester in de rechten" (Mr.) yang secara hukum masih berlaku untuk para lulusan sampai tahun 1962. Rancangan tersebut juga tercermin dari pilihan nama Ilogeschool (sekolah tinggi) yang lebih berkonotasi pendidikan ketrampilan (skill development), bukan pendidikan ilmu hukum (rechtswetenschap) yang sebenarnya. Secara lebih rinci Mochtar Kusumaatmadja mengatakan bahwa para mahasiswa disiapkan untuk pekerjaan-pekerjaan tenaga kehakiman, pegawai negeri, dan pekerjaan bebas $\left(\right.$ advokat $\left.^{26}\right)$.

Sampai dengan akhir kolonialisasi Belanda atas Indonesia, pola pendidikan tinggi hukum adalah terutama untuk melakukan pekerjaan-pekerjaan hukum pada pemerintahan. Dikatakan secara lain, para meester in de rechten adalah untuk mempertahankan status quo, yaitu mempertahankan orde hukum kolonial. Penekanannya adalah pada menjalankan hukum, sedang ma-

21. Ibid.

22. E. Fernando M. Manullang, Menggapai Hukum Berkeadilan, Tinjauan Hukum Kodrat dan Antinomi Nilai, Cetakan Pertama, Kompas, Jakarta, 2007, hlm. 1 dan 2

23. Satjipto Rahardjo, Pendidikan Hukum..., op.cit., hlm. 18 dan 19.

24. Ibid.

25. Ibid.

26. Satjipto Rahardjo, Pendidikan Hukum..., op.cit., hlm. 19 dan 20. 
salah pembuatan hukum (bagaimana membuat hukum yang baik) tidak mendapat perhatian ${ }^{27}$.

Pendidikan tinggi hukum, seiring berjalannya waktu mengalami perkem-bangan dan perubahan. Jenis pekerjaan yang diisi oleh lulusan sarjana hukum mengalami perluasan, bahkan di segala bidang pekerjaan, para lulusan sarjana hukum dapat tampil. Apapun jenis pekerjaan hukumnya, pekerjaan hukum tersebut dibutuhkan oleh masyarakat, dengan sudut pandang mengenai hukum yang berbeda tentunya.

Kehadiran hukum dalam masyarakat dapat dilihat dari bermacam-macam sudut. Para profesional hukum, seperti hakim, jaksa, advokat, dan para yuris yang bekerja di pemerintahan akan melihat dan mengartikan hukum sebagai suatu bangunan perundang-undangan. Bagi mereka tidak ada keragu-raguan lagi bahwa hukum itu tampil dan ditemukan dalam wujud perundang-undangan tersebut. Optik yang demikian itu dapat dimengerti, oleh karena pekerjaan mereka memang meng-haruskan demikian itu. Ibarat dokter yang bekerja dengan stetoskop, maka profesio-nal hukum bekerja dengan undang-undang. Di sini otoritas perundang-undangan adalah demikian besar, sehingga dapat dikatakan bahwa di luar undang-undang tidak ada hukum. Para profesional adalah golongan yuris sebagai pemain (Belanda : medespeler), sehingga mereka berhadapan dengan hukum adalah posisi yang melekat pada hukum (attached concern). Kredo mereka adalah "menyelesaikan soal dengan menerapkan undangundang ${ }^{28}$ ".

Para penstudi atau ilmuwan hukum (legal scholar, scientist) melihat hukum sebagai suatu objek yang dipelajari, yang tujuannya adalah untuk mencari kebenaran. Bagi mereka ini, hukum itu bukan barang sakral yang tidak boleh dipertanyakan atau dipersoalkan lagi, semata-mata dengan alasan bahwa itu sudah menjadi undang-undang. Kepedulian mereka adalah untuk menemukan kebenaran tentang hukum, bukan keharusan menjalankan huku. Para yuris yang masuk dalam kategori ini disebut sebagai pengamat (Belanda : toeschouwer). Posisi mereka berhadapan dengan hukum adalah mengambil jarak (detached concern). Kredo mereka adalah "pencarian dan pencerahan $^{29,}$.

Kedua golongan yuris tersebut sama-sama dibutuhkan oleh masyarakat. Di satu pihak, kehidupan seharihari yang nyata membutuhkan pedoman dan patokan konkret, dan di lain pihak membutuhkan kebenaran dari hukum yang berlaku ${ }^{30}$.

Saat ini, dunia sudah memasuki era globalisasi.
Kehidupan antar bangsa sekarang yang tanpa batas, dan persaingan bebas dalam bidang ekonomi, politik, dan ilmu pengetahuan dan teknologi.

Ini berarti seluruh rakyatnya harus menjadi warga negara dari bangsa yang modern, yang maknanya adalah warga negara yang rasional, demokratis, dan berorientasi ilmu pengetahuan dan teknologi dalam mengatasi masalah kehidupan sosial, ekonomi, dan politiknya $^{31}$.

Lulusan pendidikan tinggi hukum diharuskan untuk dapat bersaing di dalam era globalisasi, tidak hanya dengan sesama lulusan sarjana hukum, akan tetapi juga profesi lainnya. Untuk itu, setiap pendidikan tinggi hukum harus bekerja keras di dalam mencetak sarjana hukum yang mempunyai kualitas tinggi, yang tidak hanya dapat bersaing di dalam negeri sendiri, tetapi juga bersaing dengan pekerja hukum dari luar negeri. Dalam artian bahwa lulusan pendidikan tinggi hukum mempunyai daya saing global, dengan penguasaan bahasa asing yang mumpuni, khususnya tentang ilmu hukum.

Ada suatu perkembangan yang menarik di Amerika Serikat, yaitu munculnya model pendidikan hukum yang disebut Cravathism. Di sini pertautan antara hukum, pendidikan hukum dan bisnis terjalin dengan erat. Cravathism adalah "... a system at whose core is the large, nationally oriented multi-purpose commercially-oriented law firm of the type pioneered by Paul Cravath in the late 19 century". Cravathisme berpengaruh terhadap munculnya budaya "American corporate lawyering" yang menekankan pada perencanaan strategis dan advis kepada nasabah. Model lawyering tersebut "...has the capability to mobilize almost unlimited resources and all types of expertise, and operates in many legal and semi-legal arenas...". Pendidikan tinggi hukum (law schools) di Amerika berfungsi sebagai pintu masuk ke arah profesi hukum tersebut. Rupanya pengaruh Cravathism meluas ke seluruh dunia dan "demand a different kind of service" dan "look for a different academic product" "32".

Pendidikan hukum yang baik terlihat pada kualitas lawyers Amerika Serikat yang baik, yang disebut "educated first-class lawyer". Pengacara-pengacara ter-sebut disegani kemampuannya dalam masyarakat karena memiliki kualitas ketrampilan yang menonjol. Sekalipun keterampilan tersebut dalam konteks profesi, namun juga bersifat umum, yaitu ${ }^{33}$ :

1) Keterampilan analitis. Keterampilan tersebut merupakan kemampuan khusus lawyer untuk

27. Ibid.

28. Satjipto Rahardjo, Biarkan Hukum Mengalir, Catatan Kritis tentang Pergulatan Manusia dan Hukum, Cetakan Pertama, Kompas Media Nusantara, Jakarta, 2007, hlm. 1 dan 2

29. Ibid.

30. Ibid.

31. Ibid.

32. Ibid., hlm. 22 dan 23.

33. Ibid., hlm. 46-48. 
membedakan A dari B, untuk memisahkan mana yang relevan dan mana yang tidak, untuk mengurai suatu keadaan ruwet menjadi sub-sub komponen yang dapat dikelola, untuk mengamati suatu persoalan secara teliti dengan melihatnya dari berbagai perspektif;

2) Pengetahuan hukum yang mapan. Tentu saja seorang lawyer akan mempunyai spesialisasinya sendiri, tetapi sebagai seorang lawyer yang baik, harus dapat menunjuk posisi nasabahnya di tengah-tengah peta umum dari hukum positif;

3) Ketrampilan kerja yang bersifat dasar. Keterampilan tersebut berupa penghimpunan sejumlah besar informasi dan keahlian tinggi dalam melakukan komunikasi. Para first-class lawyer tahu bagaimana menulis, menggunakan perpustakaan, menjadi advokat, bagaimana mendengarkan, merancang, menginterogasi, dan tahu bagaimana memutuskan apa yang seharusnya diketahui;

4) Akrab dengan lingkungan kelembagaan. Adalah tidak cukup apabila seorang lawyer mampu memecahkan suatu persoalan, mampu untuk membuat dokumen yang cermat. Seorang "first-class lawyer" juga akrab dan mampu bekerja efektif di tengah-tengah lingkungan kelembagaan yang ada, di mana persoalan timbul. Lawyer harus mampu berhubungan dengan rakyat, untuk duduk di meja dan berunding, berdiri tegak di ruang pengadilan, mampu menggertak berbagai tetekbengek hal yang tidak nalar dalam sidang, dalam badan-badan administrasi, dalam badan perundang-undangan dan berbagai kelembagaan lain;

5) Kesadaran terhadap adanya suatu lingkungan nonhukum yang luas. Kesadaran tersebut menunjuk kepada kemampuan untuk merangkum lingkungan nonhukum dari persoalan yang dihadapinya ke dalam penyelesaian persoalan, untuk menilai dampak dari pertimbangan nonhukum yang sekiranya akan mempengaruhi hasil nanti, dan untuk menemukan jalan bagaimana memobilisasi pengetahuan dan pandangan para pihak yang bukan lawyer. Setiap persoalan hukum muncul dalam settingnya yang khas memuat pertimbangan ekonomi dan politik, serta kekuatan psikologis dan historis, masing-masing situasi menampilkan persoalannya sendiri dalam menghimpun data, mengaturnya, dan menimbang -nya. Proses hukum merupakan bagian dari suatu proses sosial yang melingkupinya; para lawyer kelas satu tidak pernah kehilangan konteks keseluruhan tersebut, dan dia tahu persis kapan harus berhubungan dengan akuntan, psikiater, dokter, ekonom, analis pasar, ahli sosiologi dan statistik serta lain-lain, yang keahliannya bisa membantu lawyer dan nasabahnya;
6) Good judgement. Pengertian tersebut susah untuk dirumuskan secara abstrak, tetapi di Amerika Serikat tampaknya orang sudah cukup maklum apabila orang mengatakan, "lawyer $X$ has good judgement" dan semua orang juga tahu, good judgement merupakan karakteristik menonjol dari seorang first-class lawyer.

Tentunya berbeda antara Indonesia dengan Amerika Serikat. Manusia Indonesia mempunyai nilai-nilai Pancasila sebagai pedoman hidup, yang tidak dimiliki oleh Amerika Serikat yang merupakan negara liberal dan kapitalis. Pendidikan tinggi hukum di Indonesia diharapkan dapat mencetak generasi penerus bangsa yang bertaqwa kepada Tuhan Yang Maha Esa dan mempunyai rasa perikemanusiaan, bukan hanya generasi penerus yang hanya memiliki skill untuk bekerja.

Sebagaimana salah satu tujuan bangsa Indonesia, yakni mencerdaskan kehidupan bangsa melalui sistem pendidikan nasional yang wajib diikuti oleh seluruh rakyat Indonesia. "Mencer-daskan kehidupan bangsa" bermakna membangun Indo-nesia menjadi negara bangsa yang maju, modern, dan demokratis, makmur, dan sejahtera berdasarkan Pancasila ${ }^{34}$.

Terdapat berbagai macam pengertian kedudukan dan fungsi Pancasila. Seluruh kedudukan dan fungsi Pancasila, bukanlah berdiri sendiri. Adapun pengertian kedudukan dan fungsi Pancasila, yakni ${ }^{35}$ :

\section{1) Pancasila sebagai jati diri bangsa Indonesia;}

Proses terjadinya Pancasila tidak seperti ideologiideologi lainnya yang hanya merupakan hasil pemikiran seseorang saja, namun melalui suatu proses kausalitas, yaitu sebelum disahkan menjadi dasar negara nilai-nilai Pancasila dalam kehidupan sehari-hari sebagai pandangan hidup bangsa dan sekaligus sebagai filsafat hidup bangsa Indonesia. Dalam pengertian inilah, maka bangsa Indonesia sebagai kausa materialis dari Pancasila. Pandangan hidup dan filsafat hidup itu merupakan kristalisasi nilai-nilai yang diyakini kebenarannya oleh bangsa Indonesia yang menimbulkan tekad bagi dirinya untuk mewujudkannya dalam sikap tingkah laku dan perbuatannya. Pandangan hidup dan filsafat hidup itu merupakan motor penggerak bagi tindakan dan perbuatan dalam mencapai tujuannya. Pandangan hidup inilah, maka dapat diketahui cita-cita yang ingin dicapai bangsa, gagasagagasan kejiwaan apakah yang hendak diwujudkan dalam kehidupan bermasyarakat, berbangsa, dan bernegara. Nilai-nilai Pancasila itu telah tercermin dalam khasanah adat-istiadat, kebudayaan serta kehidupan keagamaannya.

2) Pancasila sebagai ideologi bangsa dan negara Indo-

34. Forum Mangunwijaya, op.cit., hlm. 9 dan 10.

35. Kaelan, Filsafat Pancasila, Pandangan Hidup Bangsa Indonesia, Edisi Pertama, Paradigma, Yogyakarta, 2002, hlm. 47-65. 
nesia;

Pancasila sebagai suatu ideologi, tidak bersifat kaku dan ter-tutup, namun bersifat terbuka. Hal ini dimaksudkan bahwa ideologi Pancasila adalah bersifat aktual, dinamis, antisipatif, dan senantiasa mampu menyesuaikan dengan perkembangan jaman. Keterbukaan ideologi Pancasila bukan berarti mengubah nilai-nilai dasar Panca-sila, namun mengeksplisitkan wawasannya secara konkrit, sehingga memiliki kemampuan yang lebih tajam untuk memecahkan masalah-masalah baru dan aktual.

\section{3) Pancasila sebagai dasar filsafat negara;}

Secara yuridis, Pancasila sebagai dasar filsafat negara tertuang dalam Pembukaan Undang-Undang Dasar Negara Republik Indonesia Tahun 1945 Alinea IV yang berbunyi :

maka disusunlah kemerdekaan kebangsaan Indonesia itu dalam suatu Undang-Undang Dasar negara Indonesia, yang terbentuk dalam suatu susunan negara Indonesia yang berkedaulatan rakyat dengan berdasarkan kepada : Ketuhanan Yang Maha Esa, Kemanusiaan yang Adil dan Beradab, Persatuan Indonesia, dan Kerakyatan yang Dipimpin Oleh Hikmat Kebijaksanaan Dalam Per-musyawaratan/Perwakilan.

Melihat dan rumusan tersebut yang dimaksud... dengan berdasar kepada...adalah dalam pengertian sebagai dasar filsafat negara Indonesia. Pancasila disebut sebagai dasar filsafat negara, Philosofische Gronslag dari negara mengandung konsekuensi bahwa dalam setiap aspek penyelenggaraan negara harus sesuai dengan nilai-nilai Pan-casila. Hal itu meliputi segala peraturan perundang-undangan dalam negara, pemerintahan dan aspek-aspek kenegaraan yang lainnya. Negara adalah lembaga kemasyarakatan dalam hidup bersama. Suatu negara akan hidup dan berkembang dengan baik manakala negara tersebut memiliki dasar filsafat sebagai sumber nilai kebenaran, kebaikan, dan keadilan. Pancasila sebagai dasar filsafat negara, pada hakikatnya merupakan suatu sumber nilai bagi bangsa dan negara Indonesia, maka seluruh aspek dalam penyelenggaraan negara didasarkan dan diliputi oleh nilai-nilai Pancasila, Sehingga Pancasila sebagai dasar filsafat negara pada hakikatnya merupakan asas kerokhanian negara.

4. Pancasila sebagai asas persatuan dan kesatuan bangsa Indonesia;

Bangsa Indonesia memiliki satu asas kerokhanian, satu pandangan hidup, dan satu ideologi, yaitu Pancasila, yang ada dalam suatu negara Proklamasi 17 Agustus 1945. Bagi bangsa Indonesia adanya kesatuan asas kerokhanian, ke satuan pandangan hidup, kesatuan ideologi tersebut itu adalah amat bersifat sentral, karena suatu bangsa yang ingin berdiri kokoh dan mengetahui ke arah mana tujuan bangsa itu ingin dicapai, maka bangsa itu harus memiliki satu pandangan hidup, ideologi, maupun satu asas kerokhanian.

Bangsa Indonesia terdiri atas berbagai macam suku bangsa, yang dengan sendirinya memiliki kebudayaan dan adat-istiadat yang berbeda-beda pula. Namun demikian, bangsa perbedaan itu harus disadari sebagai sesuatu yang memang senantiasa ada pada setiap manusia (suku bangsa) sebagai makhluk pribadi, dan dalam masalah ini bersifat biasa. Namun demikian, dengan adanya kesatuan asas kerokhanian, maka perbedaan itu harus dibina ke arah suatu kerjasama dalam memperoleh kebahagiaan bersama. Dengan adanya kesamaan dan kesatuan asas kerokhanian dan ke-satuan ideologi, maka perbedaan itu perlu diarahkan pada suatu per-satuan. Di sinilah letak fungsi dan kedudukan asas kerokhanian Pancasila sebagai asas kerokhanian proses sebagai asas persatuan, kesatuan, dan asas kerjasama bangsa Indonesia.

Penyelenggaraan pendidikan tinggi hukum yang berlandaskan Pancasila, bersumber pada ajaran agama, sebagaimana ketentuan Sila Ketuhanan Yang Maha Esa dan Sila Kemanusiaan yang Adil dan Beradab. Hal ini sangat penting, mengingat kedua Sila tersebut mengajarkan nilai-nilai kebaikan, kejujuran, keadilan, kemanusiaan, dan sebagainya.

Soejadi, dkk menyatakan bahwa makna sila Ketuhanan Yang Maha Esa tidak bisa dipisahkan dengan makna agama di Indonesia, karena kausa materialis (sebab yang berupa bahan) adalah bangsa Indonesia yang sejak zaman dahulu kala telah memiliki nilai-nilai agama. Oleh karena itu, makna sila pertama tersebut perlu dijelaskan atas dasar kausa materialis (sebab yang berupa bahan) dalam proses terbentuknya Pancasila. Hal ini mengingat bahwa proses terbentuknya Pancasila selain sebagai hasil perengungan jiwa yang dalam juga merupakan suatu hasil konsensus filsafat (philosophi-cal consensus) dan konsensus politik (political consensus ${ }^{36}$ ).

Sila Ketuhanan Yang Maha Esa dalam implementasinya, terkait dengan upaya manusia untuk melaksanakan perintah Tuhan, dalam hal ini menghindari hal-hal yang dilarang oleh agama, menjadi manusia yang baik dan bertaqwa, dan mempunyai akhlak yang baik dalam bergaul dengan sesama anggota masyarakat.

Dalam kaitannya dengan sila Ketuhanan yang Maha Esa mem-punyai makna bahwa segala aspek penyelenggaraan negara harus sesuai dengan nilai-nilai yang berasal dari Tuhan. Bilamana dirinci, masalah-masalah yang menyangkut penye-lenggaraan negara antara lain meliputi penyelenggaraan negara yang bersifat material maupun yang bersifat spiritual. Hal yang bersifat material, antara lain berbentuk negara, tujuan negara, tertib hukum, sistem negara. Adapun yang bersifat kerokhanian, misalnya moral negara, moral para penyelenggaraan negara dan lain sebagainya. Dalam negara yang

36. Ibid., hlm. 143 
berdasarkan Pancasila, realisasi penyelenggaraan negara, harus dijiwai dan bersumber pada nilai-nilai yang datang dari Tuhan, yaitu kebaikan, keadilan, dan kebenaran. Hukum Tuhan senan-tiasa merupakan suatu ukuran bagi terlaksana terwujudnya hukum positif di Indonesia. Bahkan pelaksanaan bidang ekonomi, politik, pen-didikan, kesehatan, dan lain sebagainya juga harus senantiasa berdasar-kan nilai-nilai yang datang dari Tuhan ${ }^{37}$.

Apabila setiap manusia selalu melaksanakan perintah Tuhan Yang Maha Esa, akan tercipta keselarasan, kedamaian, dan kebahagiaan dalam kehidupan. Tidak ada penyimpangan, dan manusianya mempunyai moral yang baik. Pendidikan tinggi hukum berusaha mencetak generasi penerus yang demikian.

Pada Sila Kemanusiaan yang Adil dan Beradab, manusia sebagai makhluk Tuhan Yang Maha Esa, sejak lahir adalah merupakan makhluk pribadi yang tersusun atas jasmani dan rokhani. Ia memiliki akal budi dan kehendak, yang pada awalnya merupakan suatu potensi yang harus berkembang terusmenerus untuk menjadi pribadi yang sempurna dan mencapai tujuan eksistensinya. Sehubungan dengan itu, dia diberi hak asasi yaitu hak-hak manusia sebagai manusia. Dia tidak hanya berhak menggunakan hak-haknya itu, namun juga wajib menggunakannya karena hanya secara demikian, manusia dapat mengemban tugasnya dan mencapai eksistensinya ${ }^{38}$.

Sebagai realisasi isi arti Pancasila yang umum kolektif, teru-tama yang merupakan suatu ketentuan hukum positif, yang selan-jutnya merupakan pedoman bagi pelaksanaan secara khusus dan konkret dalam pelaksanaan dan penyelenggaraan negara secara operasional. Hal ini sangat penting terutama dalam menentukan ke-bijaksanaan secara operasional. Dalam kaitannya dengan karakteristik pendidikan tinggi hukum yang berlandaskan pada Sila Pertama dan Sila Kedua Pancasila, dapat disebutkan yakni ${ }^{39}$ :

1) Sila Pertama : Ketuhanan Yang Maha Esa

a) Tuhan Yang Maha Esa mengkaruniakan wilayah, tanah air Indonesia beserta kekayaan alamnya kepada bangsa Indonesia;

b) Tuhan Yang Maha Esa mengkaruniakan rakhmat atas Proklamasi Kemerdekaan bangsa Indonesia, dan berlakunya Undang-Undang Dasar Negara Republik Indonesia Tahun 1945;

c) Mewajibkan pemerintah dan penyelenggara negara untuk memelihara budi pekerti kemanusiaan yang luhur dan me-megang teguh cita-cita rakyat yang luhur;

d) Negara berdasarkan atas Ketuhan Yang Maha Esa dengan jaminan kemerdekaan bagi tiap-tiap penduduk untuk memeluk agamanya masing- masing dan untuk beribadah menurut agamanya dan kepercayaannya [Pasal 29ayat (2) UndangUndang Dasar Negara Republik Indonesia Tahun 1945;

e) Pendidikan nasional, antara lain bertujuan untuk membentuk manusia yang bertaqwa kepada Tuhan yang Maha Esa.

2) Sila Kedua : Kemanusiaan yang Adil dan Beradab

a) Jaminan hak-hak asasi warga negara, seperti tercantum da-lam Pasal 27, Pasal 28, Pasal 29 ayat (2), Pasal 30, Pasal 30 ayat (1) Undang-Undang Dasar Negara Republik Indonesia Tahun 1945:

(1) Segala warga negara bersamaan kedudukannya dalam hukum dan pemerintahan dan wajib menjunjung hukum dan pemerintahan itu dengan tidak ada kecualinya. Tiap-tiap warga negara berhak atas pekerjaan dan penghidupan yang layak bagi kemanusiaan (Pasal 27 Undang -Undang Dasar Negara Republik Indonesia Tahun 1945);

(2) Kemerdekaan berserikat dan berkumpul, mengeluarkan pikiran dengan lisan maupun tulisan dan sebagainya ditetapkan dengan undang-undang (Pasal 28 Undang-Undang Dasar Negara Republik Indonesia Tahun 1945);

(3) Negara menjamin kemerdekaan tiap-tiap penduduk untuk memeluk agamanya masingmasing dan untuk beribadah menurut agamanya dan kepercayaannya [Pasal 29 ayat (2) UndangUndang Dasar Negara Republik Indonesia Tahun 1945];

(4) Tiap-tiap warga negara berhak dan wajib, ikut serta da-lam usaha pem-belaan negara [Pasal 30 ayat (1) Undang-Undang Dasar Negara Republik Indonesia Tahun 1945];

(5) Tiap-tiap warga negara berhak mendapat pengajaran, dan pemerintah berkewajiban mengusahakan dan menyelenggarakan suatu sistem peng-ajaran negara yang diatur dengan undangundang [Pasal 31 ayat (1) dan ayat (2) UndangUndang Dasar Negara Republik Indonesia Tahun 1945].

b) Kemerdekaan adalah hak segala bangsa, maka penjajahan harus dihapuskan karena bertentangan dengan perikemanu-siaan dan perikeadilan (Pembukaan Undang-Undang Dasar Negara Republik Indonesia Tahun 1945 Alinea I);

c) Hakikat pembangunan negara Indonesia adalah pemba-ngunan manusia Indonesia seutuhnya, yaitu baik aspek jas-mani, rokhani, material, spir- 
Karakteristik Kebijakan Pendidikan Tinggi Hukum Indonesia Berdasarkan Pancasila Dan Undang-Undang Dasar Negara Republik Indonesia Tahun 1945

\section{itual (yaitu keagamaan), indi-vidu mapun masyarakat.}

Pendidikan tinggi hukum yang berlandaskan Pancasila dan Undang-Undang Dasar Negara Republik Indonesia Tahun 1945, dalam menghasilkan lulusan sarjana hukum atau sumber daya manusia yang berkualitas dan berdaya saing global, dilalui dengan tahapan-tahapan dan proses yang panjang. Dari tahap rekrutmen mahasiswa yang mempunyai minat untuk belajar ilmu hukum dan konsisten untuk melaksanakan hukum dalam kehidupan sehari-hari dan ikut serta dalam upaya penegakan hukum. Dalam prosesnya mengikuti perkuliahan atau pembelajaran, praktek, penelitian, dan pengabdian masyarakat, yang pada akhirnya sebagai hasil akhir atau output, pendidikan tinggi hukum dalam penyelenggaraannya ingin memperoleh hasil yang profilnya memenuhi 4 (empat) syarat berikut:

1) Lulusan pendidikan tinggi hukum, memiliki pengetahuan dan pemahaman tentang pentingnya nilai-nilai religi di dalam memahami dan mengamalkan pengetahuan ilmu hukum, sehingga diperlukan penguatan terhadap nilai-nilai ajaran agama;

2) Penguasaan pengetahuan di bidang ilmu hukum yang memadai;

3) Memiliki kompetensi dan keahlian yang dipraktekkan di tengah masyarakat, misalnya profesi yang dibutuhkan masyarakat seperti polisi, hakim, jaksa, pengacara, dan notaris yang dijalankan dengan penuh tanggung jawab;

4) Memiliki kemampuan dalam mengabdikan ilmu hukum di tengah masyarakat yang berdaya saing, baik nasional maupun internasional. Agar 4 (empat) kriteria tersebut terpenuhi, maka antara pengamalan nilai-nilai ajaran agama, ilmu hukum yang diperoleh selama menempuh pendidikan tinggi hukum, kemampuan yang dimiliki (skill), dan keinginan yang kuat untuk melakukan pengabdian dalam masyarakat harus selaras. Jurnal Asia Foundations sebagaimana dikutip oleh Jawade Hafidz bahwa bahwa ada 4 (empat) komponen yang mendasar dalam upaya pendidikan hukum, khususnya di Indonesia. Empat komponen yang saling terkait satu sama lain, yaitu klinik hukum, penelitian hukum yang relevan dengan isu-isu reformasi hukum, pengembangan kurikulum, dan dukungan bagi organisasi masyarakat sipil. Masing-masing komponen berfungsi memperkuat dan meningkatkan efektivitas komponen lainnya. Inti dari semua ini terletak pada klinik hukum, yang dibuat agar mahasiswa hukum diberikan kesempatan untuk mengembangkan ketrampilan praktis mereka, sesuatu yang jarang disediakan saat kuliah ${ }^{40}$.

Pada intinya bahwa pendidikan tinggi hukum pada khususnya, dan pendidikan tinggi pada umumnya, memiliki tujuan untuk mengembangkan sumber daya manusia Indonesia melalui pendidikan. Pendidikan atau yang lebih luas pembangunan sumber daya manusia, merupakan unsur yang paling strategis bagi pembangunan negara bangsa ${ }^{41}$.

F. Harbison dan C.A. Myers dalam bukunya Manpower and Education pada tahun 1965 menyatakan bahwa $^{42}$ :

In the final analysis, the wealth of a country is based on its power to develop and to effectively utilize the innats capacity of its people. The economic development of nations, therefore, is ultimately the result of human effort. It takes skilled human agents to discover and exploit natural resources, to mobilize capital, to develop technology, to produce goods, carry on trade. Indeed, if a country is unable to develop its human resources, it can not build anything else, whether it be a modern political system, a sense of national unity, or a prosperous economy.

Pernyataan yang keras dari Harbison dan Myers yang menyatakan bahwa "bila suatu negara tidak dapat mengembangkan sumber daya manusianya, negara itu tidak akan dapat mengembangkan apapun, baik sistem politik yang modern, rasa kesatuan bangsa, maupun ke -makmuran ${ }^{43}$,

Bappenas bersama BPS dan UNDP dalam publikasinya "The Economics of Democracy" menyatakan bahwa ${ }^{44}$ :

Indonesia needs to invest more in human development, not just to fulfil its people's basic rights but also to lay the foundations for economic growth and to ensure the longterm survival of its democracy. The investment is substansially but clearly affordable. It has to be based, however, on wide-spread national conceneus it could be postured.

Pendidikan yang bermakna bagi peletakan dasar pem-bangunan ekonomi dan dapat menjamin berkembangnya demokrasi memerlukan dana yang besar, dan ini sesung-guhnya sejalan dengan Amandemen Keempat terhadap Pasal 31 Undang-Undang Dasar Negara Republik Indonesia Tahun 1945 yang menetapkan agar negara mem-prioritaskan anggaran pendidikan sekurangkurangnya 20\% (dua puluh persen) Anggaran Pen-

40. Jawade Hafidz, Kontektualisasi Karakter Sistem Pendidikan Hukum Indonesia Berdasarkan Pancasila dan UUD 1945, Makalah, Fakultas Hukum Universitas Islam Sultan Agung, Semarang, 2016, hlm. 8.

41. Forum Mangunwijaya, op.cit., hlm. 11.

42. Ibid., hlm. 12 .

43. Ibid.

44. Ibid., hlm. 12 dan 13. 
dapatan Belanja Negara (APBN) dan Anggaran Pendapatan Belanja Daerah $\left(\mathrm{APBD}^{45}\right)$.

Dari hal tersebut, Negara Republik Indonesia sangat serius dalam mengembangkan pendidikan bagi rakyatnya. Rakyat wajib mengenyam pendidikan selama 9 (sembilan) tahun, dan untuk biaya pendidikan tersebut, pemerintah tidak memungut biaya sama sekali.

Tentang betapa pentingya pendidikan bagi pembangunan suatu bangsa pada abad ke-20 dan 21 ini, dianut pula oleh para pemimpin negara-negara yang merdekanya setelah Indonesia, seperti Malaysia, Singapura, Taiwan, Korea Selatan, dan China. Para pemimpin China pasca -Mao Zedong terutama Deng Xiaoping, demikian menekan-kan pentingnya pendidikan dan ini benar-benar dilaksa-nakan. Berikut adalah pandangan Deng Xiaoping tentang kedudukan strategis pendidikan : "Leaders who neglect education lack vision and matu-rity, and they are unqualified to lead the drive for modernization, that we should lay by every means to promote education, even if it means slowing down in other areas, and however poor we are we should give priority to funding for education ${ }^{46}$ ",

Dari pandangan Deng Xiaoping dapat disimpulkan bahwa seorang pemimpin yang visinya mengabaikan pendidikan, mereka tidak memenuhi syarat untuk memimpin ke arah modernisasi. Bahwa kita harus melakukan dengan segala cara untuk mempromosikan pendidikan, bahkan jika itu berarti mengurangi kegiatan di daerah lain, dan bagaimanapun miskinnya kita, kita harus memberikan prioritas untuk pendanaan untuk pendidikan.

Selanjutnya, Perdana Menteri Jiang Mien pada tahun 1993, sebagai penerus Deng Xiaoping menyatakan bahwa : "Its crucial that our economic development switches to a reliance on the advancement of science and technology and a better educated workforce, and education is given strate-gic priority to raise the moral, scientific, and cultural standards of our nations ${ }^{47, "}$.

Dapat disimpulkan dari pendapat Perdana Menteri Jiang Mien bahwa ini penting bahwa pembangunan ekonomi kita beralih ke ketergantungan pada kemajuan ilmu pengetahuan dan teknologi dan tenaga kerja terdidik yang lebih baik, dan pendidikan diberikan prioritas strategis untuk meningkatkan standar moral, ilmiah, dan budaya bangsa kita.

Pernyataan dua pemimpin China inilah yang kemudian mewujud dalam serangkaian Education Reform, yang menjadikan China mengalami kemajuan luar biasa dalam memasuki abad ke-21. Sesungguhnya, dalam hal pemikiran tentang pentingnya pendidikan, Indonesia, kalau ditelaah dari berbagai ketentuan dalam Undang-Undang Dasar Negara Republik Indonesia Tahun 1945 tidak kalah ${ }^{48}$.

Di Indonesia sebagaimana diketahui bahwa pendidikan merupakan hak warga negara. Setiap warga negara wajib mengikuti pendidikan, tanpa dikenai biaya. Pendidikan tersebut dilaksanakan untuk meningkatkan keimanan dan ketakwaan serta akhlak mulia dalam rangka mencerdaskan kehidupan bangsa.

Bahwa hanya melalui pendidikan yang bermakna, proses pembudayaan kemampuan nilai dan sikap dari suatu bangsa yang cerdas kehidupannya yang akan dapat menjadi landasan bagi pembangunan nasional yang berkesinambungan, dan untuk itulah Amandemen Keem-pat Undang-Undang Dasar Negara Republik Indonesia Tahun 1945 terutama yang menyangkut Pasal 31 ditetapkan ${ }^{49}$.

Memang terdapat perbedaan yang cukup besar bagi seseorang yang menempuh pendidikan dengan yang tidak menempuh pendidikan. Kesadaran yang tinggi dari setiap warga negara yang dibutuhkan untuk menyelenggarakan sistem pendidikan nasional dalam rangka mencerdaskan kehidupan bangsa.

Manusia Indonesia yang sesuai dengan tuntutan membangun bangsa sebagai diamanatkan Pembukaan Undang-Undang Dasar Negara Republik Indonesia Tahun 1945 adalah manusia yang bermoral, berdisiplin (pribadi, sosial, dan nasional), beretos kerja tinggi, menguasai kemampuan teknis dan profesional, memiliki sikap rasio-nal dan memiliki kemampuan intelektual, demokratis, dan bertanggung jawab. Jelas bukan manusia yang berpegang pada pandangan "ono dino ono sego (ada hari ada nasi), setiap anak membawa rezekinya sendiri-sendiri", bukan juga orang yang berpegang kepada pepatah "kalau takut dilebur pasang, jangan berumah di tepi pantai atau ono bapang den simpangi, yaitu suatu watak tidak berani menghadapi masalah". Tetapi, sebaliknya manusia yang rasional dan percaya diri serta menguasai ilmu pengetahuan dan teknologi, yang mottonya adalah " $a$ problem is a challenge and a challenge is a chance to progress (setiap masalah adalah tantangan dan tantangan adalah kesempatan untuk maju)" atau dalam bahasa Bung Karno mengutip Ki Dalang "rawe-rawe rantas malang-malang putung ${ }^{50}$ ".

Untuk membangun sumber daya manusia yang sesuai dengan harapan bangsa, tidaklah semudah membalikkan telapak tangan. Segala macam kebutuhan untuk memajukan pendidikan harus benar-benar sangat dipikirkan dan harus dipenuhi.

\footnotetext{
45. Ibid.

46. Ibid.

47. Ibid., hlm. 14.

48. Ibid.

49. Ibid.

50. Ibid., hlm. 19 dan 20.
} 
Manusia yang bermoral, berdisiplin, beretos kerja tinggi, dan mampu menguasai dan menerapkan ilmu pengetahuan dan teknologi serta demokratis dan bertanggung jawab tidak dapat dilahirkan dalam sistem pendidikan sekolah dengan peserta didik tanpa buku pelajaran, tanpa lapangan olah raga, tanpa laboratorium, tanpa perpustakaan, tanpa guru yang tidak berkomitmen kepada pendidikan anak karena rendahnya insentif dan kesejahteraan yang diterima, dan tanpa fasilitas esensial bagi sekolah sebagai pusat pembudayaan segala kemampuan, nilai, dan sikap, sehingga sekolah hanya menjadi tempat peserta didik untuk mendengar, mencatat, menghafal, dan latihan menjawab soal-soal ujian. Inilah kondisi lembaga pendidikan Indonesia pada umumnya dari Sekolah Dasar bahkan sampai tingkat universitas. Pada umumnya sekolah hanyalah tempat untuk bertemu guru di kelas. Kondisi sekolah seperti ini yang pada umumnya terdapat di negara-negara berkembang oleh Unesco dalam publikasinya pada tahun 1996 tidak dapat diharapkan untuk dapat menunjang pembangunan bang-sa melainkan sebaliknya, akan melahirkan masalahmasa-lah baru, yaitu unprepared and unskilled educated young generation $^{51}$.

Untuk suatu proses belajar, dapat dilakukan di mana saja. Hal ini berarti diperlukan fasilitas yang memadai. Bukan dengan memberlakukan waktu belajar selama mungkin, yang juga dibebani pekerjaan rumah yang harus segera diselesaikan. Manusia bukanlah sebuah mesin, yang dapat bekerja setiap waktu jika ingin digunakan. Adanya keterpaksaan, akan membuat seseorang tidak akan melakukan sesuatu secara optimal.

Proses pendidikan seperti yang sepintas disinggung dan berlangsung dari pukul 07.00 sampai pukul 12.00 tidak akan dapat mengubah karakteristik manusia Indone-sia menjadi yang beretos kerja tinggi, yang berdisiplin, yang bermoral, yang bertanggung jawab, yang menghor-mati tegaknya hukum, dan yang mampu menguasai dan menerapkan ilmu pengetahuan dan teknologi serta bersikap demokratis. Tidak lain karena masyarakat di luar sekolah, baik di rumah, di jalanan, maupun di media massa, terutama media elek-tronik belum dapat menjadi tempat yang dapat mendorong tumbuh dan berkembangnya karakteristik manusia Indo-nesia yang digambarkan dan diidealkan di atas ${ }^{52}$.

Komisi Internasional Unesco, memasuki abad ke21 merekomendasikan 4 (empat) pilar belajar, yaitu ${ }^{53}$ :

\section{1) Learning to know;}

Learning to know adalah suatu proses pembelajaran yang memungkinkan peserta didik menghayati dan akhir-nya dapat merasakan dan dapat menerapkan cara mem-peroleh pengetahuan, suatu proses yang memungkinkan tertanamnya sikap ilmiah, yaitu sikap ingin tahu dan selanjutnya menimbulkan rasa mampu untuk selalu men-cari jawab atas masalah yang dihadapi secara ilmiah.

\section{2) Learning to do;}

Sasaran akhir dari diterapkannya pilar ini adalah lahirnya generasi muda yang dapat bekerja secara cerdas dengan memanfaatkan ilmu pengetahuan dan teknologi. Pemahaman tentang pilar ini, pada berbagai jenjang pendidikan harus memungkinkan peserta didik dalam proses pembelajaran-nya sampai pada tingkatan penggunaan berbagai konsep, prinsip, atau hukum untuk memecahkan masalah yang konkret. Ini jelas memerlukan suatu lembaga pendidikan dengan tenaga guru berderajat profesional, sarana dan prasarana yang memadai dan suasana pembelajaran yang penuh tantangan.

\section{3) Learning to live together; dan}

Pendidikan tidak hanya membekali generasi muda untuk menguasai ilmu pengetahuan dan teknologi dan kemampuan bekerja serta memecahkan masalah, melainkan kemampuan untuk hidup bersama dengan orang lain yang berbeda dengan penuh toleransi, pengertian, dan tanpa prasangka. Tugas pendidikan untuk pada saat yang bersamaan, setiap peserta didik memperoleh pengetahuan dan memiliki kesadaran bahwa hakikat manusia adalah beragam, tetapi dalam keragaman tersebut terdapat persamaan. Pendidik-an untuk mencapai tingkat kesadaran akan persamaan antar sesama manusia dan terdapat saling ketergantungan satu sama lain, tidak dapat ditempuh dengan pendidikan dengan pendekatan tradisional, melainkan perlu men-ciptakan situasi kebersamaan dalam waktu yang relatif lama.

\section{4) Learning to be.}

Tiga pilar, yaitu learning to know, learning to do, dan learning to live together ditujukan bagi lahirnya generasi muda yang mampu mencari informasi dan/ atau menemu-kan ilmu pengetahuan, yang mampu melaksanakan tugas dalam memecahkan masalah secara cerdas, dan mampu bekerjasama, bertenggang rasa, dan toleran terhadap per-bedaan. Bila ketiganya berhasil dengan memuaskan akan menimbulkan adanya rasa percaya diri pada masing-masing peserta didik, hasil akhirnya adalah manusia yang mampu mengenal dirinya, dalam bahasa Undang-Undang Nomor 2 Tahun 1989 adalah manusia yang berkepribadian mantap dan mandiri. Manusia yang utuh yang memiliki kemantapan emosional dan intelektual, yang mengenal dirinya, yang dapat me-ngendalikan dirinya, yang kon-

\footnotetext{
51. Ibid., hlm. 20 dan 21.

52. Ibid.

53. Ibid., hlm. 22-27.
} 
sisten dan yang memiliki rasa empati (tepo sliro), atau dalam kamus psikologi disebut memiliki emotional intelligence. Inilah kurang lebih mak-na learning to be, yaitu muara akhir dari tiga pilar belajar.

Merupakan sebuah pekerjaan yang besar bagi bangsa Indonesia untuk membentuk karakter manusia Indone-sia menjadi yang beretos kerja tinggi, yang berdisiplin, yang bermoral, yang bertanggung jawab, yang menghor-mati tegaknya hukum, dan yang mampu menguasai dan menerapkan ilmu pengetahuan dan teknologi, bersikap demokratis, dan berdaya saing global.

1Untuk dapat menghasilkan manusia yang karakteristiknya digambarkan di atas, perlu dirancang dan dise -lenggarakan suatu sistem pendidikan nasional yang memungkinkan terjadinya proses pembelajaran yang ber-makna proses pembudayaan berbagai kemampuan, nilai, dan sikap seorang Indonesia modern yang demokratis dan bertanggung jawab ${ }^{54}$

Selain itu, hasil didikan itu sangat dipengaruhi oleh integritas kemanusiaan pendidiknya, yaitu ${ }^{55}$ :

1) Berjiwa besar ataukah bermentalitas kerdil;

2) Jujur ataukah koruptif;

3) Bersahaja atau serba semu, apalagi bermewahmewah;

4) Konsekuen ataukah angin-anginan, mengikuti liak-liuk irama gendang seruling yang membiuskan menghanyutkan.

Di sini, pendidik atau dosen atau guru juga mempengaruhi pembentukan karakter dari anak didik. Apa yang dilakukan oleh pendidik, tentunya akan ditiru oleh anak didiknya, sehingga kualitas pendidik juga menentukan kualitas sumber daya manusia yang dihasilkan.

Tetap berpegang teguh pada nilai-nilai Pancasila dan Undang-Undang Dasar Negara Republik Indonesia Tahun 1945, merupakan kunci bagi pembangunan karakter manusia Indonesia. Bangsa Indonesia lahir dengan sejumlah ciri khas, sifat-sifat, serta nilai-nilai yang dimilikinya sejak zaman dahulu kala, sehingga mem-bedakan bangsa Indonesia dengan bangsa lainnya. Maksud kepribadian bangsa dan negara Indonesia adalah terdiri atas jumlah sifat-sifat yang tetap terlekat bangsa Indonesia, yang terdiri atas ${ }^{56}$ :

1) Hakikat abstrak manusia "monopluralis", yang bersifat tetap dan terlekat pada semua orang dan sifatnya umum universal. Sifat-sifat tersebut adalah unsur tubuh (raga), jiwa, akal, rasa, kehendak; makhluk individu dan makhluk sosial; makhluk pribadi berdiri sendiri dan makhluk Tuhan yang dalam hal ini tersimpul dalam kata pokok sila kedua, yaitu "kemanusiaan". Hal ini berarti bahwa setiap orang memiliki sifat-sifat hakikat abstrak tersebut, yang sifatnya umum universal. Oleh karena itu, sifat ini ada pada setiap manusia tidak terkecuali, misalnya orang Jerman, India, Arab, Amerika, Be-landa, dan lain sebagainya, termasuk juga orang Indonesia. Konsekuensinya bahwa dalam pengertian kepribadian Indonesia juga tersimpul nilai-nilai kemanusiaan yang sifatnya universal, maka kepribadian Indonesia juga tersimpul di dalamnya kepribadian kemanusiaan, yang berarti memiliki sifat-sifat dan ciri-ciri kemanusiaan yang sifatnya univer-sal;

2) Hakikat pribadi Indonesia, yaitu keseluruhan sifatsifat dan ciri-ciri khusus yang tetap, yang terlekat pada diri pribadi bangsa Indo-nesia, sehingga menyebabkan bangsa Indonesia berbeda dengan bangsa lain. Ciri khas kepribadian Indonesia itu terkandung dalam seluruh isi sila kedua, yaitu "Kemanusiaan yang Adil dan Beradab" dalam hubungan kesatuannya dengan sila-sila yang lainnya. Hal ini berarti bahwa kepribadian Indonesia terdiri atas kepribadian "Kemanusiaan yang Adil dan Beradab" yang berKetuhanan Yang Ma-ha Esa, berPersatuan Indonesia, berKerakyatan yang Dipimpin Oleh Hikmat Kebijaksanaan Dalam Permusyawaratan/perwakilan, dan yang berKeadilan Sosial Bagi Seluruh Rakyat Indonesia. Maka secara keseluruhan disebutkan bahwa kepribadian Indonesia adalah ke-pribadian Pancasila.

Apabila karakteristik kebijakan pendidikan tinggi hukum Indonesia berlandaskan nilai-nilai Pancasila dan Undang-Undang Dasar Negara Republik Indonesia Tahun 1945, akan dengan mudah membangun sumber daya manusia yang berkualitas dan berdaya saing global.

Sungguh sangat mengilhami apa yang disebut Galanter dengan "alleviating human sufferings" dan Spence agar para profesional hukum "need to be evolved persons". Dunia pendidikan tinggi hukum, perlu merenungkan kata-kata mutiara tersebut, kemudian menjabarkannya ke dalam fokus serta arah pendidikan hukum. Diperlukan sejenak untuk merenung dan menentukan apa yang dapat dan akan dilakukan agar pendidikan tinggi hukum benar-benar berguna bagi rakyat. Salah satu aspek yang perlu diperhatikan terhadap pendidikan tinggi hukum adalah mengutamakan "pengembangan kemanusiaan" di atas keinginan menghasilkan manusia hukum ${ }^{57}$ ".

Hal yang terpenting adalah manfaat dari keberadaan pendidikan tinggi hukum bagi masyarakat. Sangat disayangkan apabila pendidikan tinggi hukum mampu mencetak para pekerja hukum yang profesion-

\footnotetext{
54. Ibid., hlm. 21 dan 22.

55. Abdul Ghofur Anshori dan Shobirin Malian (Ed.), op.cit., hlm. 61.

56. Kaelan, op.cit., hlm. 175 dan 176.

57. $\quad$ Forum Mangunwijaya, op.cit., hlm. 37.
} 
al dan berkualitas tinggi, akan tetapi di dalam masyarakat, keberadaannya tidak diakui dan tidak memberikan kontribusi bagi masyarakat. Di sinilah tugas pemerintah dan seluruh rakyat Indonesia untuk bekerjasama dalam meningkatkan pendidikan nasional, agar sumber daya manusia Indonesia diakui di mata internasional.

Paradigma hukum di era perkembangan pada abad ke-21 ini, "hukum" harus memiliki terobosan langkah di samping hukum itu sendiri bersifat progresif, namun tetap utuh menjadi pijakan dasar keadilan yang harus berevolusi menjadi "keadilan-sungguh", baik dalam konteks edukasi bagi para pengajar dan pelajar hukum dalam menghadapi tantangan global dimasing-masing perguruan tinggi sampai pada praktek senyatanya. Langkah perubahan yang mendesak adalah ${ }^{58}$.

1) Reformasi kurikulum pendidikan hukum berbasis mutualisme antara hukum nasional dan hukum internasional. Mengapa, karena persaingan di dunia global, yang berakibat juga terhadap persaingan perguruan tinggi di dalam negeri maupun di luar negeri, sehingga perguruan tinggi dituntut untuk menghasilkan lulusan yang dapat bersaing dalam dunia global;

2) Bergesernya orientasi pendidikan tinggi yang tidak lagi hanya menghasilkan manusia cerdas berilmu, tetapi juga yang mampu menerapkan keilmuannya dalam kehidupan di masyarakatnya (kompeten dan relevan), yang lebih berbudaya, harus dipupuk secara sumber daya kemanusiaan (pengajar), dan berbasis kompetensi internasional;

3) Bahwa orientasi pendidikan hukum bukan sekedar mencerdaskan kehidupan bangsa, namun menciptakan mutualisme keadilan dan kemanusiaan yang berbasis pada ideologi Pancasila dan UndangUndang Dasar Negara Republik Indonesia Tahun 1945;

4) Pergeseran "need humanity", kebutuhan di dunia kerja sudah terwujud sebagai kondisifikasi persyaratan dalam menerima tenaga kerja, yaitu adanya persyaratan softskills yang dominan di samping hardskillsnya. Bahwa kekuatan teori saja tidak cukup kapabel dalam menyelesaikan persoalan hukum. Hukum harus dibarengi dengan kelincahan gerak para penegak hukum itu sendiri yang tidak menyimpang dari aturan.

Empat hal di atas adalah the basic need of character hukum dalam menghadapi tantangan global yang harus segera disiapkan di level pendidikan tingkat tinggi dan dipraktekkan kepada lembaga-lembaga negara dengan seadil-adilnya, tanpa ada keberpihakan stakeholder terhadap putusan hukum itu sendiri. Di sini hukum diuji, penegak hukum dipantau oleh kekuasaan di atas hukum itu sendiri berupa kejujuran dan keadilan ${ }^{59}$

\section{III.SIMPULAN}

Pendidikan adalah hak setiap warga negara, sebagaimana diamanatkan dalam Pasal 31 UndangUndang Dasar Negara Republik Indonesia Tahun 1945. Tujuan pendidikan adalah untuk mencerdaskan kehidupan bangsa. Pendidikan merupakan salah satu dalam upaya pembangunan bangsa. Pendidikan, termasuk dan terutama pendidikan tinggi merupakan faktor yang menentukan keberhasilan pem-bangunan suatu negara, terutama ekonomi.

Pendidikan tinggi yang merupakan bagian dari sistem pendidikan nasional memiliki peran strategis dalam mencerdaskan kehidupan bangsa dan memajukan ilmu pengetahuan dan teknologi. Pendidikan tinggi diharapkan dapat menjadi pencetak sumber daya manusia yang profesional, berdaya guna, dan bersaing, termasuk di sini adalah pendidikan tinggi hukum.

Negara Indonesia sendiri, mempunyai ciri khusus dalam penyelenggaraan pendidikan tinggi hukum, yakni dengan bersumber pada ajaran agama sebagai basis filosofisnya, sebagaimana yang terdapat di dalam sila Pancasila terutama Sila Ketuhanan Yang Maha Esa, yang mana pendidikan nasional, antara lain bertujuan untuk membentuk manusia yang bertaqwa kepada Tuhan yang Maha Esa dan Sila Kemanusiaan Yang Adil dan Beradab, yang mana pendidikan merupakan hak asasi warga negara, sebagaimana diamanatkan dalam Pasal 31 ayat (1) dan ayat (2) Undang-Undang Dasar Negara Republik Indonesia Tahun 1945. Dari segi sosiologis, masyarakat sangat membutuhkan pendidikan. Dalam dunia pendidikan, terjadi interaksi sosial. Satu dan yang lainnya akan saling bertukar pikiran. Selain itu, apa yang diajarkan oleh pendidik akan membawa pengaruh bagi anak didiknya, terutama dalam pembangunan kualitas sumber daya manusia dan karakter anak didik yang dihasilkan.

Lulusan pendidikan tinggi hukum diharuskan untuk dapat bersaing di dalam era globalisasi, tidak hanya dengan sesama lulusan sarjana hukum, akan tetapi juga profesi lainnya. Lulusan pendidikan tinggi hukum harus mempunyai daya saing global, dengan penguasaan bahasa asing yang mumpuni, khususnya tentang ilmu hukum.

Pendidikan tinggi hukum dalam penyelenggaraannya ingin memperoleh hasil yang profilnya memenuhi 4 (empat) syarat berikut:

1) Lulusan pendidikan tinggi hukum, memiliki pengetahuan dan pemahaman tentang pentingnya nilainilai religi di dalam memahami dan mengamalkan 
Karakteristik Kebijakan Pendidikan Tinggi Hukum Indonesia Berdasarkan Pancasila Dan Undang-Undang Dasar Negara Republik Indonesia Tahun 1945

pengetahuan ilmu hukum, sehingga diperlukan penguatan terhadap nilai-nilai ajaran agama;

2) Penguasaan pengetahuan di bidang ilmu hukum yang memadai;

3) Memiliki kompetensi dan keahlian yang dipraktekkan di tengah masyarakat, misalnya profesi yang dibutuhkan masyarakat seperti polisi, hakim, jaksa, pengacara, dan notaris yang dijalankan dengan penuh tanggung jawab;

4) Memiliki kemampuan dalam mengabdikan ilmu hukum di tengah masyarakat yang berdaya saing, baik nasional maupun internasional. Agar 4 (empat) kriteria tersebut terpenuhi, maka antara pengamalan nilai-nilai ajaran agama, ilmu hukum yang diperoleh selama menempuh pendidikan tinggi hukum, kemampuan yang dimiliki (skill), dan keinginan yang kuat untuk melakukan pengabdian dalam masyarakat harus selaras.

\section{DAFTAR PUSTAKA}

\section{Buku}

Abdul Ghofur Anshori dan Shobirin Malian (Ed.), Membangun Hukum Indonesia, Kumpulan Pidato Guru Besar Ilmu Hukum dan Filsafat, Cetakan Pertama, Kreasi Total Media, Yogyakarta, 2008.

Fernando M. Manullang, Menggapai Hukum Berkeadilan, Tinjauan Hukum Kodrat dan Antinomi Nilai, Cetakan Pertama, Kompas, Jakarta, 2007.
Forum Mangunwijaya, Kurikulum yang Mencerdaskan, Visi 2030 dan Pendidikan Alternatif, Cetakan Pertama, Kompas Media Nusantara, Jakarta, 2007.

Kaelan, Filsafat Pancasila, Pandangan Hidup Bangsa Indonesia, Edisi Pertama, Paradigma, Yogyakarta, 2002.

Satjipto Rahardjo, Biarkan Hukum Mengalir, Catatan Kritis tentang Pergulatan Manusia dan Hukum, Cetakan Pertama, Kompas Media Nusantara, Jakarta, 2007.

, Pendidikan Hukum Sebagai Pendidikan Manusia, Kaitannya Dengan Profesi Hukum dan Pembangunan Hukum Nasional, Cetakan Kesatu, Genta Publishing, Yogyakarta, 2009.

\section{Makalah}

Jawade Hafidz, Kontektualisasi Karakter Sistem Pendidikan Hukum Indonesia Berdasarkan Pancasila dan UUD 1945, Makalah, Fakultas Hukum Universitas Islam Sultan Agung, Semarang, 2016. 